Adrian Sadlowski

Uniwersytet Kardynata Stefana Wyszyńskiego w Warszawie

\title{
Skutki stosowania płatności redystrybucyjnej w zależności od wariantu wdrożeniowego na przykładzie Polski
}

\section{THE CONSEQUENCES OF USING DIFFERENT VARIANTS OF IMPLEMENTATION OF REDISTRIBUTIVE PAYMENT - A CASE STUDY OF POLAND}

\begin{abstract}
$W$ niniejszym opracowaniu, $w$ ramach badań diagnostycznych, dokonano pomiaru aktualnego stopnia koncentracji pomocy dystrybuowanej $w$ ramach systemu wsparcia bezpośredniego dla rolników $w$ Polsce oraz przedstawiono jego zróżnicowanie regionalne. $Z$ kolei $w$ ramach badań symulacyjnych dokonano kwantyfikacji skutków redystrybucyjnych stosowania$w$ różnych wariantach - instrumentu wyrównujacego przyznawane kwoty wsparcia między gospodarstwami. Może to stanowić podstawe oceny ex ante alternatywnych opcji wdrożeniowych płatności redystrybucyjnej. Badania doprowadziły m.in. do wyznaczenia przedziałów obszarowych gospodarstw korzystajacych na stosowaniu płatności redystrybucyjnej - w obecnym ksztatcie oraz $w$ przyktadowych wariantach alternatywnych. W części końcowej artykułu sformułowano kilka rekomendacji $w$ zakresie projektowania płatności redystrybucyjnej na poziomie krajowym w zależności od celów, które maja być osiagane za pomocq tego instrumentu.
\end{abstract}

Słowa kluczowe: Wspólna Polityka Rolna, płatności bezpośrednie, płatność redystrybucyjna, Polska

JEL Code: Q18

\section{Wprowadzenie}

Zasadniczo od momentu przystapienia do Unii Europejskiej stosowany w Polsce system wsparcia bezpośredniego dla rolników zawsze w dużym stopniu uzależniał kwotę otrzymanego wsparcia od powierzchni użytków rolnych w gospodarstwie. Z badań P. Gracy-Gelert odnoszących się do okresu 2005-2010, których celem było m.in. oszacowanie wpływu płatności bezpośrednich na zróżnicowanie dochodów gospodarstw domowych w Polsce, wynika, że pogłębiały one zróżnicowanie tych dochodów, trafiając przede wszystkim do bogatszych grup społecznych - rolników wielkoobszarowych. ${ }^{1}$ $\mathrm{Z}$ drugiej strony w systemie wsparcia bezpośredniego upatruje się istotnego czynnika hamującego pozytywne zmiany strukturalne $\mathrm{w}$ polskim rolnictwie, wskazując, że gospodarstwa generujące niskie dochody ze sprzedaży produktów rolnych często przedkładają coroczny, niewielki, ale stabilny dochód w postaci płatności bezpośrednich nad jednorazowy przychód ze sprzedaży ziemi dynamicznym gospodarstwom znacznie

1 P. Graca-Gelert: Wpływ funduszy unijnych na zróżnicowanie dochodów w Polsce - przykład dopłat bezpośrednich i rent strukturalnych. Nierówności Społeczne a Wzrost Gospodarczy, nr 38 (2/2014), s. 189. 
silniej ukierunkowanym na produkcję towarowa. ${ }^{2}$ Przy takim podejściu płatności kierowane do małych gospodarstw uznawane są jako czynnik petryfikujący niekorzystną strukturę obszarową polskiego rolnictwa, mimo że indywidualne kwoty trafiające do poszczególnych małych gospodarstw są stosunkowo niewielkie.

N. Baisakova i T. Herzfeld wymieniają redystrybucję środków na korzyść mniejszych gospodarstw wśród najważniejszych elementów ostatniej reformy Wspólnej Polityki Rolnej w I filarze. ${ }^{3}$ Polska od samego początku, to jest od 2015 r., korzysta $\mathrm{z}$ wprowadzonej w ramach tej reformy możliwości stosowania specjalnego instrumentu, którego celem jest zmniejszenie różnic między gospodarstwami w kwotach przyznanej pomocy, czyli tzw. płatności redystrybucyjnej. Z motywu 36 preambuły do rozporządzenia Parlamentu Europejskiego i Rady (UE) nr 1307/2013 ${ }^{4}$ odnoszącego się do płatności redystrybucyjnej wynika, że instrument ten ma być narzędziem zwiększenia skali wsparcia - w ramach systemu płatności bezpośrednich - dochodów małych gospodarstw rolnych ponad poziom wynikający z tego, że kwota pomocy przydzielonej $\mathrm{w}$ formie najbardziej powszechnego instrumentu wsparcia stosowanego $\mathrm{w}$ ramach tego systemu, czyli płatności podstawowej ( $w$ systemie opartym na uprawnieniach) bądź jednolitej płatności obszarowej (w systemie uproszczonym), zasadniczo jest proporcjonalna do powierzchni użytkowanych rolniczo gruntów w gospodarstwie. Instrument ten może być jednocześnie narzędziem stymulowania pozytywnych zmian strukturalnych $\mathrm{w}$ rolnictwie. Komisja Europejska dopuszcza bowiem nieobejmowanie płatnością początkowego przedziału hektarów w gospodarstwie. Jest równoznaczne z tym, że gospodarstwa o powierzchni nie większej niż górna granica tego początkowego przedziału nie będą beneficjentami płatności redystrybucyjnej, będą natomiast niejako ją finansować, bowiem otrzymają niższe wsparcie w postaci jednolitej płatności obszarowej niż w sytuacji, w której płatność redystrybucyjna nie byłaby stosowana.

Analizowanie w usystematyzowany sposób dylematów polityki gospodarczej i dokonanie prawidłowej oceny różnych możliwych działań państwa wymagają rozpoznania skutków różnych alternatywnych wariantów działania oraz stworzenia odpowiednich kryteriów oceny tych wariantów, mając na względzie zakładane cele. ${ }^{5}$ Celem opracowania jest wsparcie procesów decyzyjnych dotyczących projektowania płatności redystrybucyjnej w Polsce (w tym wprowadzania zmian w zasadach jej przyznawania lub poziomie finansowania) poprzez:

1) dokonanie - w ramach diagnozowania sytuacji wyjściowej - pomiaru aktualnego stopnia koncentracji pomocy,

2) przeprowadzenie symulacji, pozwalających na ocenę ex ante skutków redystrybucyjnych różnych wariantów wdrożeniowych, oraz

\footnotetext{
${ }^{2}$ M. Kwasowski, S. Zaleski: Die Landwirtschaft in Polen fünf Jahre nach dem Beitritt zur Europäischen Union. Polen-Analysen, Nr. 51/09, Deutsches Polen-Institut Darmstadt und Forschungsstelle Osteuropa, Bremen 2009, s. 4.

${ }^{3}$ N. Baisakova, T. Herzfeld: Aspekte der Agrarpolitik 2013. German Journal of Agricultural Economics, 63 (2014) (Supplement), s. 5.

${ }^{4}$ Motyw ten brzmi następująco: „Uwzględniając potrzebę, aby jednolite wsparcie dla rolników posiadających małe gospodarstwa rolne było wystarczające, aby osiagnąc cel, jakim jest skuteczne wsparcie dochodu, należy zezwolić państwom członkowskim na ponowny rozdział wsparcia bezpośredniego między rolników poprzez przyznanie im dodatkowej płatności za pierwsze hektary.”.

${ }^{5}$ J.E. Stiglitz: Ekonomia sektora publicznego. Wydawnictwo Naukowe PWN, Warszawa 2004, s. 20-21.
} 
3) przedyskutowanie wyników przeprowadzonych badań.

Tego rodzaju badania pozwalają bardziej świadomie i racjonalnie projektować kształt tego instrumentu - tak, aby stanowił on jak najlepsze narzędzie osiagania stawianych przed nim celów.

\section{Metodyka badań i materiał źródłowy}

W ramach przeprowadzonych badań, wykorzystując metody ilościowe, dokonano symulacji skutków zastosowania alternatywnych opcji wdrożeniowych płatności redystrybucyjnej w Polsce, co umożliwiło przeprowadzenie komparatywnej analizy wariantowej. Zmierzono wpływ następujących zmian w zasadach przyznawania lub poziomie finansowania płatności redystrybucyjnej na średnią kwotę wsparcia na hektar w gospodarstwie w zależności od jego wielkości:

a) zwiększenie poziomu finansowania płatności redystrybucyjnej do maksymalnego dopuszczalnego przepisami unijnymi poziomu, to jest do $30 \%$ pułapu krajowego (wariant I).

b) maksymalne rozszerzenie przedziału hektarów objętego płatnością redystrybucyjna, to jest objęcie wsparciem „pierwszych hektarów” w gospodarstwie w liczbie nie większej niż 30 (wariant II).

c) zwiększenie poziomu finansowania płatności redystrybucyjnej do $30 \%$ pułapu krajowego, a jednocześnie objęcie wsparciem „pierwszych hektarów” w gospodarstwie w liczbie nie większej niż 30 (wariant III).

Do pomiaru nierównomierności rozdziału łącznej puli środków, rozdysponowywanych $\mathrm{w}$ ramach systemu wsparcia bezpośredniego, między poszczególnych rolników stanowiących zbiorowość beneficjentów tego systemu, posłużono się współczynnikiem Giniego.

Materiał źródłowy stanowiły dane Ministerstwa Rolnictwa i Rozwoju Wsi oraz Agencji Restrukturyzacji i Modernizacji Rolnictwa.

\section{Zakres decyzyjności państwa czlonkowskiego}

Mając na względzie zasadę subsydiarności, przydzielono państwom członkowskim Unii Europejskiej stosunkowo szerokie uprawnienia odnoszące się do płatności redystrybucyjnej. Obejmują one możliwość podjęcia decyzji o stosowaniu bądź niestosowaniu płatności redystrybucyjnej (jej wdrożenie jest bowiem fakultatywne dla państw członkowskich), o poziomie finansowania tego instrumentu (czyli wielkości środków przeznaczonych do wypłaty rolnikom w ramach płatności redystrybucyjnej) oraz o jego kształcie (czyli zasadach przyznawania tej płatności).

Zgodnie $\mathrm{z}$ przepisami unijnymi, $\mathrm{w}$ danym państwie członkowskim $\mathrm{w}$ ramach płatności redystrybucyjnej może zostać wypłacona rolnikom łączna kwota w wysokości nie przekraczającej $30 \%$ tzw. pułapu krajowego, to jest całkowitej puli środków przydzielonych temu państwu na dany rok do rozdysponowania $w$ ramach systemu wsparcia bezpośredniego. Oprócz ograniczenia polegającego na określeniu maksymalnego dopuszczalnego łącznego poziomu wsparcia wszystkich beneficjentów płatności redystrybucyjnej, w przepisach unijnych ustanowiono jednocześnie zasadę, że stawka tej płatności nie może przekraczać $65 \%$ średniej krajowej płatności na hektar, 
obliczonej jako stosunek pułapu krajowego na 2019 r. do powierzchni objętej jednolitą płatnością obszarową w $2015 \mathrm{r}$. Jest to więc ograniczenie polegające na określeniu maksymalnego dopuszczalnego jednostkowego poziomu wsparcia. W razie konieczności, czyli w przypadku gdy stosunek puli środków wydzielonej na finansowanie płatności redystrybucyjnej do powierzchni zatwierdzonej do tej płatności jest wyższy niż 65\% średniej krajowej płatności na hektar, państwo członkowskie jest zobowiązane dokonać liniowej redukcji tak wyliczonej pierwotnej stawki płatności redystrybucyjnej, aby rzeczywiście obowiązująca stawka nie przekraczała dopuszczalnego limitu.

Poza wyznaczeniem poziomu finansowania płatności redystrybucyjnej (w granicach limitu ustanowionego $\mathrm{w}$ przepisach Unii Europejskiej) państwo członkowskie decyduje o kształcie tego instrumentu, wskazując przedział hektarów w gospodarstwie, który ma być objęty płatnością. Przedział ten musi się jednak mieścić $\mathrm{w}$ granicach wyznaczonych przepisami unijnymi. Dolną granicą przedziału, w którym musi się zawierać, bądź z którym musi się pokrywać przedział hektarów w gospodarstwie objęty płatnością redystrybucyjna, jest 0 ha. Natomiast górną granicę stanowi 30 ha albo średnia powierzchnia gospodarstwa w $\mathrm{kraju}^{6}-\mathrm{w}$ zależności od tego, który $\mathrm{z}$ tych limitów jest wyższy. Ponadto państwo członkowskie ma możliwość progresywnego bądź degresywnego stopniowania stawki płatności w wyodrębnionych podprzedziałach hektarowych.

Zgodnie z propozycjami Komisji Europejskiej co do kształtu Wspólnej Polityki Rolnej po $2020 \mathrm{r}^{7}$, w kolejnej perspektywie finansowej państwa członkowskie mają mieć jeszcze większe możliwości kształtowania tego instrumentu ${ }^{8}$ na poziomie krajowym, przy czym ma to być instrument obligatoryjny dla państw członkowskich. Większa swoboda w kwestii kształtowania tego instrumentu na poziomie krajowym ma kilka źródeł. Po pierwsze, projektowane przepisy unijne, w przeciwieństwie do obecnie obowiązujących, nie określają górnej granicy przedziału hektarowego, do którego może być przyznawana płatność. Po drugie, projektowane przepisy przewidują odejście od ustanawiania dopuszczalnego poziomu finansowania płatności redystrybucyjnej. Po trzecie, projektowane przepisy unijne przewidują złagodzenie ograniczenia odnoszącego się do maksymalnego dopuszczalnego jednostkowego poziomu wsparcia poprzez zwiększenie dopuszczalnej relacji stawki płatności redystrybucyjnej do średniej krajowej płatności na hektar z 65\% do 100\%. Zmiany te zwiększą potencjał płatności redystrybucyjnej jako instrumentu oddziaływania na rzeczywistość gospodarczą, w tym niwelowania różnic między rolnikami w kwotach otrzymywanego wsparcia.

\section{Wariant wdrożeniowy zastosowany w Polsce}

Od początku stosowania płatności redystrybucyjnej do bieżącego roku, czyli w okresie 2015-2019, poziom finansowania tego instrumentu w ujęciu kwotowym corocznie

\footnotetext{
6 Średnie wielkości gospodarstw rolnych w poszczególnych państwach członkowskich zestawiono w załączniku VIII do rozporządzenia Parlamentu Europejskiego i Rady (UE) nr 1307/2013.

${ }^{7}$ Propozycje te znalazły wyraz w projekcie rozporządzenia Parlamentu Europejskiego i Rady (COM(2018) 392).

${ }^{8}$ Przy czym w wyniku reformy Wspólnej Polityki Rolnej zmieni się nazewnictwo instrumentów wsparcia. Odpowiednikiem płatności redystrybucyjnej w nowym systemie płatności bezpośrednich ma być „,uzupełniające redystrybucyjne wsparcie dochodu do celów stabilności”.
} 
wzrastał, a w ujęciu względnym - wynosił co najmniej $8,3 \%$ pułapu krajowego. Średniorocznie na jego finansowanie przeznaczono niemal 289 mln EUR, co stanowi prawie $8,5 \%$ średniorocznego pułapu krajowego obliczonego dla tego okresu. Wysokość stawki płatności redystrybucyjnej $\mathrm{w}$ poszczególnych latach analizowanego okresu oscylowała w przedziale między 40 a $42 \mathrm{EUR} / \mathrm{ha}$, a maksymalna kwota wsparcia w ramach tego instrumentu - w przedziale między 1080 a 1125 EUR. Informacje te zestawiono w tabeli 1 .

Tabela 1. Poziom finansowania i stawka płatności redystrybucyjnej oraz maksymalna kwota wsparcia na gospodarstwo w ramach tego instrumentu w Polsce w latach 2015-2019

\begin{tabular}{|c|c|c|c|c|c|c|}
\hline \multicolumn{2}{|c|}{ Rok } & 2015 & 2016 & 2017 & 2018 & 2019 \\
\hline \multirow{2}{*}{ Poziom finansowania } & mln EUR & 280,42 & 281,81 & 289,80 & 293,93 & 298,04 \\
\hline & \% pułapu krajowego & $8,30 \%$ & $8,30 \%$ & $8,49 \%$ & $8,57 \%$ & $8,64 \%$ \\
\hline Stawka & EUR/ha & 40,07 & 40,01 & 41,13 & 41,62 & 42,25 \\
\hline $\begin{array}{l}\text { Maksymalna } \\
\text { jednostkowa kwota } \\
\text { wsparcia }\end{array}$ & EUR/gospodarstwo & 1081,89 & 1080,27 & 1110,51 & 1123,74 & 1140,76 \\
\hline
\end{tabular}

Źródło: opracowanie własne na podstawie danych Ministerstwa Rolnictwa i Rozwoju Wsi.

Stawka płatności redystrybucyjnej w Polsce - jako że zgodnie z przepisami unijnymi nie może przekraczać $65 \%$ średniej krajowej płatności na hektar - nie może być wyższa niż 158,63 EUR/ha ${ }^{9}$. W odniesieniu do płatności redystrybucyjnej przyznawanej na obecnych zasadach ograniczenie to jest tylko pozorne. Przekroczenie poziomu $65 \%$ średniej krajowej płatności na hektar wymagałoby bowiem niemal czterokrotnego zwiększenia poziomu finansowania płatności redystrybucyjnej, podczas gdy - ze względu na limit w wysokości 30\% pułapu krajowego - możliwe byłoby zwiększenie tego poziomu ok. 3,5-krotnie.

Kolejnym ograniczeniem przy projektowaniu rozwiązań dotyczących płatności redystrybucyjnej na poziomie krajowym - obok dopuszczalnego poziomu finansowania (wyrażonego jako odsetek pułapu krajowego) i dopuszczalnej wysokości stawki płatności (wyrażonej jako odsetek średniej krajowej płatności na hektar) - jest górna granica przedziału hektarów w gospodarstwie, który może być objęty wsparciem w ramach tego instrumentu. Ze względu na to, że średnia powierzchnia gospodarstwa w Polsce jest mniejsza niż 30 ha (wynosi 6 ha), w przypadku Polski tę górną granicę stanowi 30 ha.

Projektując płatność redystrybucyjną na poziomie krajowym uznano, że grupa docelową pomocy dystrybuowanej $\mathrm{w}$ ramach tego instrumentu mają być gospodarstwa średniej wielkości, które - nie osiagając tak dużych korzyści ze skali produkcji, jak gospodarstwa największe - dysponuja jednak znaczącym potencjałem rozwojowym ${ }^{10}$. W związku z tym zdecydowano się na objęcie płatnością redystrybucyjną przedziału

\footnotetext{
${ }^{9}$ Średnia krajowa płatność na hektar wynosi w przypadku Polski 244,05 EUR/ha.

${ }^{10}$ Ministerstwo Rolnictwa i Rozwoju Wsi: Projekt systemu płatności bezpośrednich w latach 2015-2020

Warszawa 2015, s. 11.
} 
hektarów $(3 ; 30]^{11}$. Takie rozwiązanie dopuszcza Komisja Europejska, uznając je za szczególny przypadek gradacji stawki ${ }^{12}-\mathrm{z}$ zerową stawką dla początkowego przedziału hektarów $(0 ; 3]$. Z noty informacyjnej Komisji Europejskiej dotyczącej implementacji przez państwa członkowskie płatności redystrybucyjnej w latach $2015-2020^{13}$ wynika, że Polska jest jedynym krajem stosującym dolny próg w wysokości innej niż 0 ha.

Zatem płatność redystrybucyjna jest przyznawana w Polsce do nadwyżki powierzchni użytków rolnych w gospodarstwie, do której przyznano jednolitą płatnością obszarowa, ponad 3 ha, nie większej jednak niż 27 ha. Stąd maksymalną roczną kwotę wsparcia pojedynczego gospodarstwa $\mathrm{w}$ ramach płatności redystrybucyjnej $\mathrm{w}$ danym roku stanowi iloczyn 27 ha i stawki płatności za dany rok. Kwoty w tej wysokości otrzymują wszystkie gospodarstwa, w których powierzchnia użytków rolnych objęta jednolitą płatnością obszarową wynosi przynajmniej 30 ha. Ich wysokość dla poszczególnych lat zestawiono $\mathrm{w}$ ostatnim wierszu tabeli 1.

\section{Grupa obszarowa gospodarstw korzystająca na obecnie stosowanym rozwiązaniu}

Konsekwencją wydzielenia określonej kwoty na finansowanie płatności redystrybucyjnej jest niższy o tę właśnie kwotę poziom finansowania jednolitej płatności obszarowej. Dlatego stosowanie płatności redystrybucyjnej jest korzystne de facto tylko dla części jej beneficjentów. Każdy beneficjent płatności redystrybucyjnej jest bowiem jednocześnie beneficjentem jednolitej płatności obszarowej, zatem z punktu widzenia gospodarstwa będącego beneficjentem płatności redystrybucyjnej istotny jest bilans netto realokacji środków między tymi instrumentami, czyli różnica między przyznaną kwotą płatności redystrybucyjnej a ubytkiem wsparcia $\mathrm{w}$ ramach jednolitej płatności obszarowej. Obliczenie stawki jednolitej płatności obszarowej, która obowiazywałaby w sytuacji niestosowania płatności redystrybucyjnej, umożliwia wyznaczenie granicznych dla efektu redystrybucyjnego wielkości gospodarstw, stanowiących granice przedziałów powierzchniowych gospodarstw tracących/korzystających na stosowaniu płatności redystrybucyjnej.

Z przeprowadzonych obliczeń wynika, że w $2018 \mathrm{r}$. gospodarstwa o powierzchni mniejszej niż 5,9 ha oraz gospodarstwa o powierzchni większej niż 54,6 ha straciły na wprowadzeniu płatności redystrybucyjnej $\mathrm{w}$ obecnym kształcie. Dla tej populacji gospodarstw bilans stosowania płatności redystrybucyjnej jest ujemny. Każde z gospodarstw reprezentujących te grupy obszarowe otrzymałoby większą kwotę

\footnotetext{
${ }^{11}$ Znalazło to odzwierciedlenie w art. 14 ustawy z dnia 5 lutego 2015 r. o płatnościach w ramach systemów wsparcia bezpośredniego (Dz. U. z 2017 r. poz. 278, ze zm.).

${ }^{12} \mathrm{~W}$ przepisach projektowanych na kolejną perspektywę finansową taka możliwość jest dopuszczona wprost poprzez wskazanie, że płatność redystrybucyjna może być ukierunkowana na grupę gospodarstw średniej wielkości. W motywie 29 preambuły do rozporządzenia Parlamentu Europejskiego i Rady (COM(2018) 392) stwierdzono bowiem: „Z uwagi na potwierdzona potrzebe promowania bardziej zrównoważonego podziału wsparcia na rzecz małych lub średnich gospodarstw rolnych w bardziej widoczny i mierzalny sposób, należy ustanowić na poziomie unijnym specjalną płatność niezwiązaną $\mathrm{z}$ wielkością produkcji na hektar, tj. uzupełniajace redystrybucyjne wsparcie dochodu do celów stabilności. (...)”, a w art. 26 ust. 2 - „Państwa członkowskie zapewniają redystrybucję wsparcia od większych do mniejszych lub średnich gospodarstw rolnych przez zapewnienie redystrybucyjnego wsparcia dochodu (...)".

${ }^{13}$ European Commission: Redistributive payment. 2016, s. 4.
} 
pomocy, gdyby nie stosowano płatności redystrybucyjnej, a w konsekwencji środki przeznaczone na jej finansowanie zostałyby rozdysponowane w ramach jednolitej płatności obszarowej. ${ }^{14} \mathrm{Z}$ kolei gospodarstwa o powierzchni większej niż 5,9 ha, ale mniejszej niż 54,6 ha korzystają na stosowaniu płatności redystrybucyjnej w obecnym kształcie. W ich przypadku ubytek kwoty wsparcia $w$ ramach jednolitej płatności obszarowej jest z nadwyżką kompensowany wielkością środków przyznanych $\mathrm{w}$ formie płatności redystrybucyjnej. Natomiast dla gospodarstw o granicznych powierzchniach stosowanie płatności redystrybucyjnej jest neutralne $\mathrm{z}$ punktu widzenia kwoty otrzymanej płatności. Zatem przedział wielkości gospodarstw korzystających na stosowaniu płatności redystrybucyjnej (5,9 ha; 54,6 ha) jest szerszy od przedziału hektarów w gospodarstwie, do których przyznawana jest ta płatność (3 ha; 30 ha], i przesunięty względem niego w prawo.

Ogólnie rzecz biorąc, gospodarstwa zyskujące na wprowadzeniu płatności redystrybucyjnej to te gospodarstwa, w których łączna kwota wsparcia w ramach jednolitej płatności obszarowej i płatności redystrybucyjnej podzielona przez powierzchnię użytków rolnych jest wyższa niż stawka jednolitej płatności obszarowej, która obowiązywałaby w sytuacji niestosowania płatności redystrybucyjnej. Obrazuje to rysunek 1, na którym linia ciagła wykreślona dla wariantu zastosowanego w $2018 \mathrm{r}$. przebiega nad poziomą kropkowaną kreską wykreśloną dla wariantu alternatywnego bez płatności redystrybucyjnej w przypadku gospodarstw o powierzchni większej niż 5,9 ha, ale mniejszej niż 54,6 ha.

\footnotetext{
${ }^{14}$ Należy zauważyć, że płatności redystrybucyjnej nie otrzymują jedynie gospodarstwa o powierzchni do 3 ha. Zatem tylko część gospodarstw tracących na stosowaniu płatności redystrybucyjnej w obecnym kształcie nie otrzymuje tej płatności.
} 


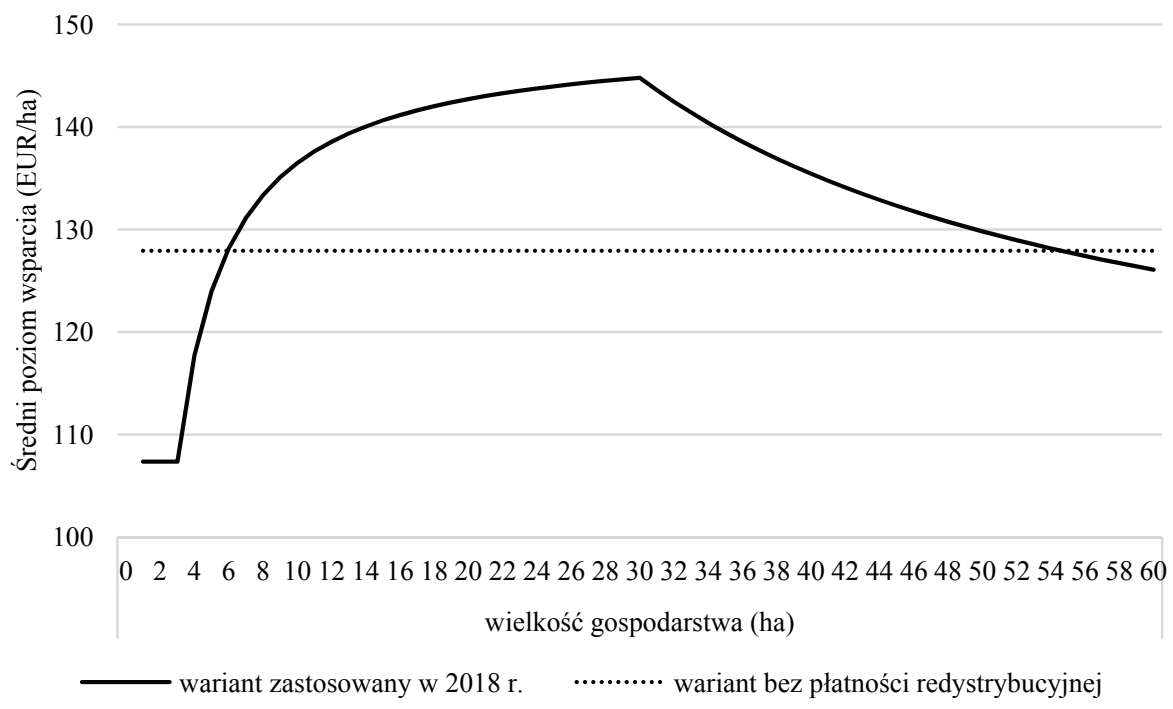

Rysunek 1. Wysokość średniej kwoty wsparcia na hektar w ramach jednolitej płatności obszarowej i płatności redystrybucyjnej (wariant zastosowany w 2018 r.) bądź wyłącznie w ramach jednolitej płatności obszarowej (wariant bez płatności redystrybucyjnej) w zależności od wielkości gospodarstwa

Źródło: opracowanie własne na podstawie danych Agencji Restrukturyzacji i Modernizacji Rolnictwa.

W zastosowanym wariancie średnia kwota wsparcia na hektar gruntów jest stała i równa stawce jednolitej płatności obszarowej jedynie dla gospodarstw o powierzchni nie większej niż 3 ha (obrazuje to poziomy początkowy odcinek ciągłej linii na rysunku 1). Wraz $\mathrm{z}$ przekroczeniem dolnej granicy przedziału hektarów w gospodarstwie objętego płatnością redystrybucyjną, średnia kwota wsparcia na hektar gruntów rośnie aż do osiagnnięcia górnej granicy tego przedziału. Zatem najwyższą średnią osiagną gospodarstwa o powierzchni równej 30 ha (przy tej wielkości gospodarstwa wykres funkcji wykreślony na rysunku 1 linią ciąłą osiąga apogeum). Wraz z dalszym wzrostem wielkości gospodarstwa średnia kwota wsparcia na hektar maleje, zbliżając się asymptotycznie do linii poziomej, która byłaby wykreślona na wysokości stawki jednolitej płatności obszarowej (to jest 107,35 EUR/ha). Dzieje się tak dopóty, dopóki nie ujawnią się skutki stosowania tzw. mechanizmu redukcji płatności, ustanowionego w art. 11 rozporządzenia Parlamentu Europejskiego i Rady (UE) nr 1307/2013. W 2018 r. w Polsce stosowanie tego mechanizmu oddziaływało na gospodarstwa o powierzchni przekraczającej 1397,3 ha $^{15}$, dlatego od tego momentu dynamika spadku średniej kwoty wsparcia na hektar gruntów jest większa.

\footnotetext{
${ }^{15}$ W Polsce zastosowano współczynnik redukcji w maksymalnej wysokości (czyli 100\%), co oznacza, że pojedyncze gospodarstwo może otrzymać jednolitą płatność obszarową w kwocie nie większej niż 150 tys. EUR. Zatem graniczny próg wielkościowy gospodarstwa, którego przekroczenie skutkuje redukcją płatności, można obliczyć, dzieląc 150 tys. EUR przez stawkę jednolitej płatności obszarowej (107,35 EUR/ha).
} 
Natomiast w wariancie bez płatności redystrybucyjnej w przypadku wszystkich gospodarstw o powierzchni nie większej niż 1 172,5 ha ${ }^{16}$, średnia kwota wsparcia na hektar w ramach jednolitej płatności obszarowej i płatności redystrybucyjnej w istocie równałaby się stawce jednolitej płatności obszarowej. Rysunek 1 nie sięga tak dużych argumentów funkcji, dlatego średnia kwota wsparcia na hektar dla tego wariantu jest obrazowana dla całego ujętego na rysunku zakresu zmienności wielkości gospodarstwa linią poziomą (kropkowaną). Gospodarstwa przekraczające próg powierzchniowy w wysokości 1 172,5 ha byłyby objęte mechanizmem redukcji płatności, wskutek czego od tego momentu średnia kwota wsparcia na hektar malałaby wraz ze wzrostem wielkości gospodarstwa.

\section{Symulacja skutków zastosowania przykładowych opcji alternatywnych}

Przedmiotem porównawczej analizy wariantowej w niniejszej części artykułu są następujące zmiany w obszarze poziomu finansowania lub kształtu płatności redystrybucyjnej na poziomie krajowym:

a) Wariant I - zwiększenie poziomu finansowania płatności redystrybucyjnej do maksymalnego dopuszczalnego przepisami unijnymi poziomu (to jest do $30 \%$ pułapu krajowego).

Zwiększenie puli środków przeznaczonej na płatność redystrybucyjną odbywa się kosztem jednolitej płatności obszarowej. Konsekwencją zmiany poziomu finansowania płatności redystrybucyjnej jest zatem taka sama co do wartości bezwzględnej, a przeciwna co do kierunku zmiana poziomu finansowania jednolitej płatności obszarowej. W wariancie tym zasady przyznawania płatności redystrybucyjnej nie różnią się od dotychczas stosowanych, czyli wsparcie w ramach tego instrumentu kierowane jest do hektarów z przedziału (3; 30], a stawka płatności jest stała w całym przedziale hektarowym objętym pomoca.

b) Wariant II - maksymalne rozszerzenie przedziału hektarów objętego płatnością redystrybucyjną (to jest objęcie wsparciem „pierwszych hektarów” w gospodarstwie w liczbie nie większej niż 30).

W wariancie tym przewiduje się zmianę zasad przyznawania płatności redystrybucyjnej przy zachowaniu obecnego rocznego poziomu finansowania tego instrumentu w ujęciu absolutnym, wynoszącego niecałe $294 \mathrm{mln}$ EUR. Brak zmian w poziomie finansowania płatności redystrybucyjnej w ujęciu kwotowym oznacza automatycznie brak zmian (w stosunku do obecnie stosowanego rozwiązania) w kwotach jednolitej płatności obszarowej przyznanej poszczególnym gospodarstwom. Zmiana zasad przyznawania płatności redystrybucyjnej $\mathrm{W}$ porównaniu do dotychczas stosowanego rozwiązania polega na objęciu płatnością również hektarów z przedziału $(0 ; 3]$. Po tej modyfikacji przedział hektarowy, do którego kierowane jest wsparcie w

\footnotetext{
${ }^{16}$ Tę graniczną wielkość gospodarstwa obliczono w ten sam sposób, jak dla wcześniej omawianego wariantu, czyli dzieląc 150 tys. EUR przez stawkę jednolitej płatności obszarowej, przy czym dla omawianego w tym miejscu wariantu stawka jednolitej płatności obszarowej jest wyższa (wynosi 127,93 EUR/ha), stąd w wyniku dzielenia otrzymano mniejszą graniczną wielkość gospodarstwa.
} 
ramach płatności redystrybucyjnej, to $(0 ; 30]$. Biorąc pod uwagę unijne regulacje dotyczące płatności redystrybucyjnej, jest to najszerszy zakres hektarowy możliwy do zastosowania w przypadku Polski.

c) Wariant III - zwiększenie poziomu finansowania płatności redystrybucyjnej do $30 \%$ pułapu krajowego, a jednocześnie objęcie wsparciem „pierwszych hektarów" w gospodarstwie w liczbie nie większej niż 30.

Wariant ten łączy w sobie obie opisane wyżej modyfikacje stanowiące warianty I i II.

Dokonano kwantyfikacji wpływu zastosowania tych wariantów na średnią kwotę wsparcia w gospodarstwie, a wyniki pomiarów zwizualizowano przy pomocy wykresów.

Wyniki symulacji obrazującej, jak kształtowałby się średni poziom wsparcia gospodarstwa rolnego na jednostkę powierzchni użytków rolnych (w ramach jednolitej płatności obszarowej oraz płatności redystrybucyjnej) w zależności od wielkości gospodarstwa oraz zastosowanego wariantu wdrożeniowego płatności redystrybucyjnej, przedstawiono na rysunku 2.

$\mathrm{Z}$ rysunku 2 wynika, że w stosunku do obecnie stosowanego wariantu:

a) wariant I poprawia sytuację finansową gospodarstw o powierzchni większej niż 5,9 ha, ale mniejszej niż 54,6 ha kosztem wszystkich pozostałych gospodarstw;

b) wariant II poprawia sytuację finansowa gospodarstw o powierzchni do 9,0 ha kosztem wszystkich pozostałych gospodarstw;

c) wariant III poprawia sytuacje finansową gospodarstw o powierzchni nie przekraczającej 35,2 ha kosztem wszystkich pozostałych gospodarstw.

Ponadto na podstawie rysunku 2 można stwierdzić, że wariant I cechuje największe, a wariant II najmniejsze zróżnicowanie średniego poziomu wsparcia na hektar między gospodarstwami. 


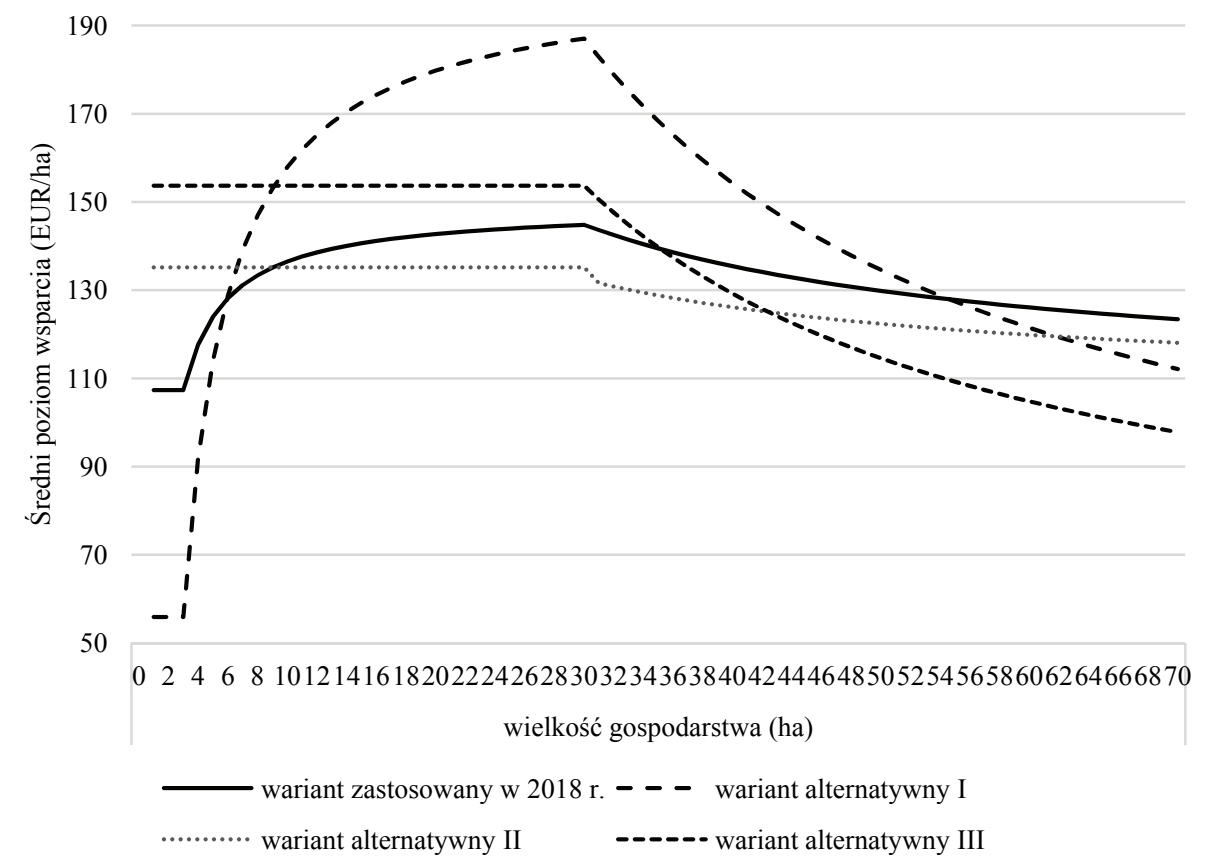

Rysunek 2. Wysokość średniej kwoty wsparcia na hektar w ramach jednolitej płatności obszarowej i płatności redystrybucyjnej w zależności od wielkości gospodarstwa w różnych wariantach wdrożeniowych płatności redystrybucyjnej

Źródło: opracowanie własne na podstawie danych Agencji Restrukturyzacji i Modernizacji Rolnictwa.

Dodatkowo można zauważyć, że w przypadku wariantów, w których dolna granica przedziału objętego płatnością redystrybucyjną jest większa od 0 (wariant zastosowany w 2018 r. i wariant I), największą średnią kwotę wsparcia na hektar powierzchni gruntów otrzymałyby gospodarstwa o powierzchni równej górnej granicy przedziału hektarów w gospodarstwie objętego płatnością redystrybucyjną (wykres analizowanej funkcji osiaga apogeum dla $x=30$ ). Natomiast w przypadku wariantów, w których płatność redystrybucyjna byłaby przyznawana od ,pierwszych hektarów” (wariant II i wariant III) najwyższą kwotę wsparcia na hektar otrzymałyby gospodarstwa o powierzchni nie większej niż górna granica tego przedziału.

\section{Koncentracja pomocy dystrybuowanej w ramach systemu wsparcia bezpośredniego}

Cechą charakterystyczną pomocy rozdzielanej $\mathrm{w}$ ramach systemu wsparcia bezpośredniego dla rolników jest duża koncentracja. Jest to konsekwencja wynikającego z zasad przyznawania płatności - silnego związku między kwotą otrzymanego wsparcia a powierzchnią gospodarstwa, w warunkach dużego zróżnicowania gospodarstw pod względem wielkości mierzonej powierzchnią 
użytkowanych gruntów. Koncentrację tę zmniejszają instrumenty takie jak płatność redystrybucyjna czy mechanizm redukcji płatności.

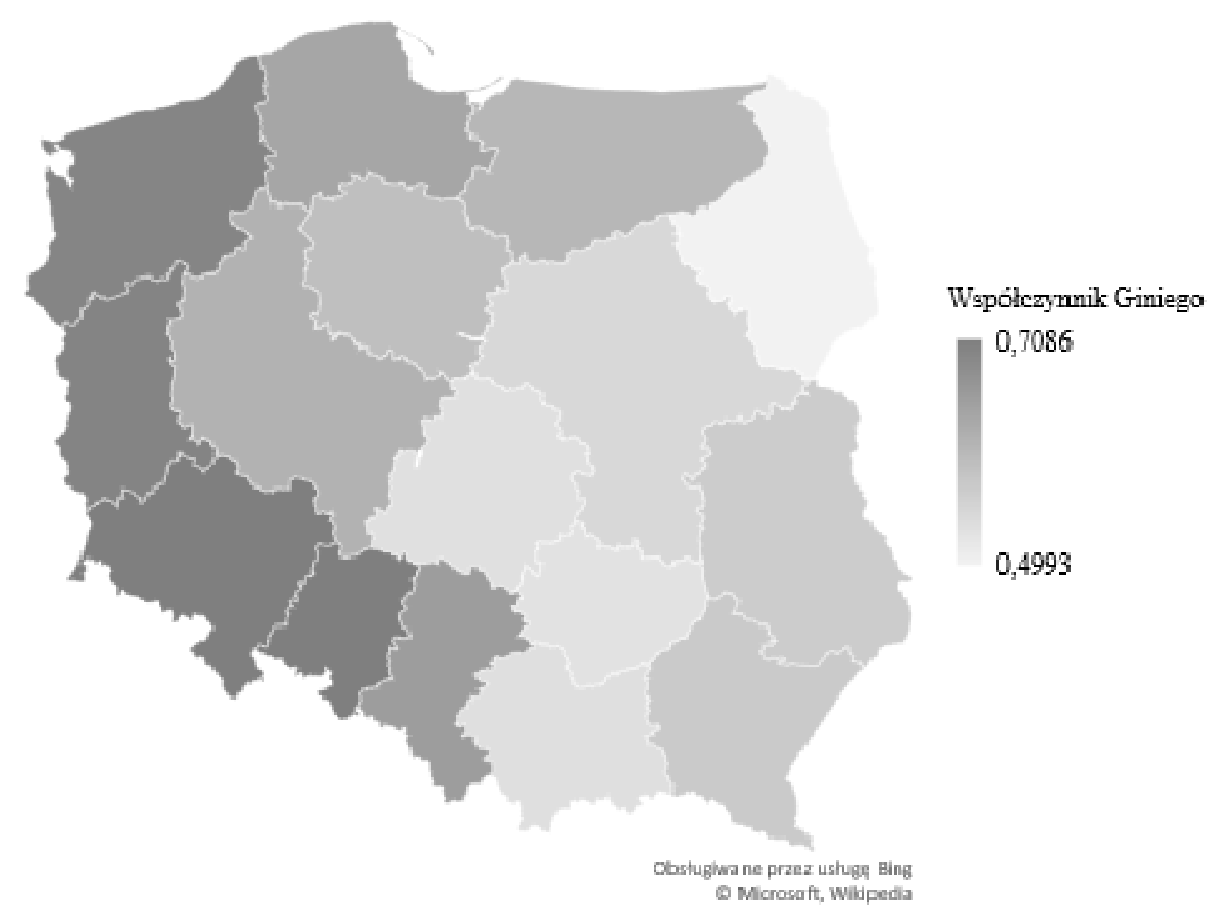

Rysunek 3. Regionalne zróżnicowanie koncentracji pomocy dystrybuowanej w ramach systemu wsparcia bezpośredniego w $2018 \mathrm{r}$.

Źródło: opracowanie własne na podstawie danych Agencji Restrukturyzacji i Modernizacji Rolnictwa.

Współczynnik koncentracji pomocy dystrybuowanej w ramach systemu wsparcia bezpośredniego obliczony dla Polski na podstawie danych dotyczących 2018 r. wynosi 0,63 . Ten sam wskaźnik obliczony dla $2014 \mathrm{r}$. wyniósł natomiast $0,61^{17}$, a więc był nieco niższy, mimo że wówczas nie stosowano jeszcze płatności redystrybucyjnej.

Wartości współczynnika Giniego są dość silnie zróżnicowane regionalnie. Zostało to zobrazowane na kartogramie przedstawionym na rysunku 3, z którego wynika, że w 2018 r. największa część pomocy zaabsorbowanej przez dany region trafiła do najmniej licznych gospodarstw w województwach Polski Zachodniej oraz w województwie opolskim. Natomiast najbardziej równomiernie, w porównaniu do innych województw, pomoc została rozdzielona w województwie podlaskim.

${ }^{17}$ A. Sadłowski: Podział środków w ramach systemu wsparcia bezpośredniego pomiędzy beneficjentów analiza nierównomierności i instrumenty redystrybucyjne wprowadzone w 2015 roku. Zagadnienia Ekonomiki Rolnej, 4(353) 2017, s. 175. 


\section{Podsumowanie}

Przepisy Unii Europejskiej umożliwiają państwom członkowskim w dużym stopniu samodzielne zaprojektowanie płatności redystrybucyjnej. Daje to możliwość ukształtowania tego instrumentu stosownie do lokalnych uwarunkowań i priorytetów przyjętych na poziomie krajowym.

Płatność redystrybucyjna może być instrumentem pobudzania pozytywnych zmian strukturalnych w rolnictwie. Nieobejmowanie płatnością pewnego zakresu „pierwszych hektarów" (co jest równoznaczne z wyłączeniem najmniejszych rolników z grona beneficjentów tego instrumentu) pozwala silniej wesprzeć gospodarstwa o preferowanej wielkości, a wysoki poziom finansowania płatności redystrybucyjnej zapewnia przy tym stosunkowo duży rozdźwięk między średnim poziomem wsparcia na hektar w grupie gospodarstw o powierzchni mniejszej niż dolna granica przedziału objętego płatnością redystrybucyjną a gospodarstwami o preferowanej wielkości. Konsekwencją jest relatywne obniżenie zdolności konkurowania na rynku grupy najmniejszych gospodarstw, a jednocześnie stworzenie silniejszych bodźców do powiększania wielkości obszarowej gospodarstw w celu uzyskiwania wyższych kwot pomocy w przeliczeniu na hektar powierzchni gruntów. W ten sposób płatność redystrybucyjna może przyczyniać się do wzrostu poziomu koncentracji ziemi, a tym samym - do zwiększenia średniej wielkości gospodarstwa, zwłaszcza w drodze powiększania gospodarstw najmniejszych przy jednoczesnym spadku ich liczebności. Takie rozwiązanie może sprzyjać ewolucji sektora rolnego w kierunku sektora w większym stopniu zintegrowanego $\mathrm{z}$ otoczeniem i zdolnego do trwałego funkcjonowania na rynku.

Przeciwdziałaniu absorbcji stosunkowo dużej części środków przyznawanych w ramach systemu wsparcia bezpośredniego przez stosunkowo nieliczną grupę gospodarstw (czyli zmniejszaniu koncentracji pomocy dystrybuowanej w ramach tego systemu) sprzyja ustanowienie zasady przyznawania wsparcia $\mathrm{w}$ ramach płatności redystrybucyjnej od „pierwszych hektarów” oraz wydzielenie na finansowanie tego instrumentu maksymalnej dopuszczalnej przepisami unijnymi kwoty. Bardziej egalitarny podział środków dystrybuowanych $\mathrm{w}$ ramach systemu wsparcia bezpośredniego może mieć pewne uzasadnienie w związku z realizacją celów quasi-socjalnych oraz dążeniem do bardziej sprawiedliwego rozdysponowania środków, zasadniczo może jednak odbywać się kosztem obniżenia efektywności sektora w wytwarzaniu produktów rolnych.

\section{Bibliografia}

Baisakova N., Herzfeld T.: Aspekte der Agrarpolitik 2013. German Journal of Agricultural Economics, 63 (2014) (Supplement)

European Commission: Redistributive payment. 2016.

Graca-Gelert P.: Wplyw funduszy unijnych na zróżnicowanie dochodów w Polsce-przykład dopłat bezpośrednich i rent strukturalnych. Nierówności Społeczne a Wzrost Gospodarczy, $\mathrm{nr} 38$ $(2 / 2014)$.

Kwasowski M., Zaleski S.: Die Landwirtschaft in Polen fünf Jahre nach dem Beitritt zur Europäischen Union. Polen-Analysen, Nr. 51/09, Deutsches Polen-Institut Darmstadt und Forschungsstelle Osteuropa, Bremen 2009. 
Ministerstwo Rolnictwa i Rozwoju Wsi: Projekt systemu płatności bezpośrednich w latach 20152020. Warszawa 2015.

Projekt rozporządzenia Parlamentu Europejskiego i Rady ustanawiającego przepisy dotyczące wsparcia na podstawie planów strategicznych sporządzanych przez państwa członkowskie w ramach wspólnej polityki rolnej (planów strategicznych WPR) i finansowanych z Europejskiego Funduszu Rolniczego Gwarancji (EFRG) i z Europejskiego Funduszu Rolnego na rzecz Rozwoju Obszarów Wiejskich (EFRROW) oraz uchylającego rozporządzenie Parlamentu Europejskiego i Rady (UE) nr 1305/2013 i rozporządzenie Parlamentu Europejskiego i Rady (UE) nr 1307/2013 (COM(2018) 392).

Rozporządzenie Parlamentu Europejskiego i Rady (UE) nr 1307/2013 z dnia 17 grudnia 2013 r. ustanawiające przepisy dotyczące płatności bezpośrednich dla rolników na podstawie systemów wsparcia w ramach wspólnej polityki rolnej oraz uchylające rozporządzenie Rady (WE) $\mathrm{nr}$ 637/2008 i rozporządzenie Rady (WE) nr 73/2009 (Dz. Urz. UE L 347 z 20.12.2013, s. 608, ze zm.).

Sadłowski A.: Podział środków $w$ ramach systemu wsparcia bezpośredniego pomiędzy beneficjentów - analiza nierównomierności i instrumenty redystrybucyjne wprowadzone $w 2015$ roku. Zagadnienia Ekonomiki Rolnej, 4(353) 2017.

Stiglitz J.E.: Ekonomia sektora publicznego. Wydawnictwo Naukowe PWN, Warszawa 2004.

Ustawa z dnia 5 lutego 2015 r. o płatnościach w ramach systemów wsparcia bezpośredniego (Dz. U. z 2017 r. poz. 278 , ze zm.).

\section{Summary}

The article describes a diagnostic study measuring the degree of concentration of the aid which is currently distributed under the direct support system for farmers in Poland; it also presents the regional differentiation in aid concentration. The author conducted a simulation test quantifying the redistributive effects of applying various variants of an instrument equalising the amounts of support granted to farms. This can make the basis for an ex-ante assessment of alternative options of the implementation of redistributive payment. The research enabled the identification of ranges of the areas of farms which benefit from the current shape of redistributive payment and which may benefit from alternative variants given as examples. The final part of the article contains several recommendations on how to design redistributive payment at a national level, depending on the goals to be achieved with this instrument.

Keywords: Common Agricultural Policy, direct payments, redistributive payment, Poland JEL: Q18

Informacja o autorze:

\section{dr Adrian Sadłowski}

Uniwersytet Kardynała Stefana Wyszyńskiego w Warszawie

Wydział Społeczno-Ekonomiczny

ul. Wóycickiego $1 / 3$, bud. 23

01-938 Warszawa

e-mail: a.sadlowski@uksw.edu.pl

ORCID: 0000-0003-2969-4926 